\title{
PENGETAHUAN GIZI, KELUHAN KESEHATAN, KONDISI PSIKOLOGIS, DAN POLA PEMBERIAN ASI IBU POSTPARTUM
}

\author{
(Nutritional Knowledge, Health Complaints, Psychological Condition, and Breastfeeding Patterns \\ on Postpartum Mothers)
}

\author{
Armina Puji Utari1 ${ }^{1 *}$, Katrin Roosita ${ }^{1}$, dan M. Rizal M.Damanik ${ }^{1}$ \\ 'Departemen Gizi Masyarakat, Fakultas Ekologi Manusia, Institut Pertanian Bogor, 16680
}

\begin{abstract}
This study was aimed to assess nutritional knowledge, health complaints, psychological conditions, and their association with breastfeeding pattern on postpartum mother. A cross sectional study with interview method was conducted in five villages in Dramaga Subdistrict, Bogor District, during the period of April to May 2013. Subjects included in this study were 30 postpartum mothers who met inclusion criteria. Subjects were mothers of 10-40 days old newborn baby and it was not the first childbirth, willing to be subject through informed consent agreement, and was able to communicate. The majority of postpartum mothers had fair nutritional knowledge (60.0\%), low health complaints (66.7\%), and depression (56.7\%). The nutritional knowledge of exclusive breastfeeding tended to correlate with exclusive breastfeeding practice ( $r=0.126$; $p=0.508)$. Meanwhile, lower health complaints tended to correlate with better breastfeeding practices $(r=0.063 ; p=0.74)$.
\end{abstract}

Keywords: breastfeeding, health complaints, nutritional knowledge, postpartum mother, psychological conditions

\begin{abstract}
ABSTRAK
Penelitian ini bertujuan untuk mengetahui pengetahuan gizi, status kesehatan, kondisi psikologis serta kaitannya dengan pola pemberian ASI ibu postpartum. Penelitian ini menggunakan desain cross sectional study dengan metode wawancara yang dilakukan di lima desa di Kecamatan Dramaga, Kabupaten Bogor, pada bulan April hingga Mei 2013. Subjek penelitian adalah 30 ibu postpartum dengan kriteria inklusi, ibu dari bayi berusia 10-40 hari dan bukan persalinan pertama, bersedia menjadi subjek penelitian, dan dapat berkomunikasi dengan baik. Hasil penelitian menunjukkan bahwa sebagian besar ibu postpartum memiliki tingkat pengetahuan gizi cukup (60\%), keluhan kesehatan rendah (66.7\%) serta mengalami depresi $(56.7 \%)$. Pengetahuan gizi tentang definisi ASI yang semakin baik pada ibu postpartum cenderung berkorelasi dengan pemberian ASI eksklusif yang baik $(r=0.126 ; p=0.508)$. Sebaliknya, semakin rendah keluhan kesehatan ibu postpartum, cenderung berkorelasi dengan pola pemberian ASI yang semakin baik $(r=0.063 ; p=0.74)$.
\end{abstract}

Kata kunci: ASI, ibu postpartum, keluhan kesehatan, kondisi psikologis, pengetahuan gizi

"Korespondensi: Departemen Gizi Masyarakat, Fakultas Ekologi Manusia (FEMA), Institut Pertanian Bogor, Bogor 16680. Email: arminapujiutari@gmail.com 


\section{PENDAHULUAN}

Tujuan pembangunan millenium atau Millennium Development Goals (MDGs) yang terkait langsung dengan pembangunan kesehatan antara lain meningkatkan kesehatan ibu dan menurunkan angka kematian bayi (AKB). World Health Organization (WHO) menetapkan target di tahun 2015 untuk mengurangi dua pertiga tingkat kematian ibu dalam proses melahirkan dan dua pertiga tingkat kematian bayi atau anak-anak di bawah usia lima tahun. Angka kematian ibu (AKI) dan angka kematian bayi (AKB) juga merupakan salah satu tolak ukur ketercapaian kesejahteraan rakyat (Depkes RI 2013).

Survei Dasar Kesehatan Indonesia (SDKI) 2007 menunjukkan bahwa AKI tahun 2003-2007 sebesar 228 per 100000 kelahiran hidup. AKB Indonesia juga masih tergolong tinggi jika dibandingkan dengan negara-negara ASEAN, yaitu 1.3 kali lebih tinggi dari Filipina, 1.8 kali lebih tinggi dari Thailand dan 4.6 kali lebih tinggi dari Malaysia (Depkes RI 2013). Tingginya angka kematian neonatal (AKN) dan AKI menunjukkan pentingnya memperhatikan periode postpartum karena merupakan periode pemulihan setelah proses melahirkan yang membutuhkan pengobatan dan perawatan. Selain itu, periode postpartum merupakan periode awal proses laktasi atau pemberian ASI (Prawiroharjo 2008).

Hasil survei Centers for Disease Control and Prevention (CDC), menunjukkan bahwa pada tahun 2009 sebesar $16.3 \%$ bayi di dunia diberikan ASI eksklusif selama enam bulan, dan sebesar $76.9 \%$ diberikan ASI eksklusif selama satu tahun (CDC 2012). Sementara itu hasil di Indonesia, persentase bayi yang menyusui eksklusif sampai dengan enam bulan sebesar 15.3\% (RISKESDAS 2010).

Pola pemberian ASI berkaitan dengan kondisi psikologis postpartum. Hasil penelitian dari Klainin dan Arthur (2009) mengungkapkan bahwa sebesar 3.5-63.3\% perempuan di Asia mengalami gangguan psikologi setelah melahirkan, dengan prevalensi terendah di Malaysia dan tertinggi di Pakistan. Taveras et al. 2003 juga mengungkapkan bahwa gangguan psikologis ini dapat berpengaruh terhadap hubungan antara ibu dan bayi serta pola menyusui. Identifikasi sejak awal terhadap risiko gangguan psikologis pada ibu postpartum sangat penting untuk mengurangi pengaruh negatif kondisi psikologi ini dan berpotensi untuk meningkatkan keberhasilan pemberian ASI.

Kondisi pengetahuan gizi, keluhan kesehatan, dan gangguan psikologis ibu postpartum diduga memiliki pengaruh terhadap pola pemberian ASI. Berdasarkan hal tersebut perlu diteliti keterkaitan antara pengetahuan gizi, keluhan kesehatan, dan kondisi psikologis terhadap pola pemberian ASI Ibu postpartum.

Tujuan dari penelitian ini adalah untuk menilai tingkat pengetahuan gizi, keluhan kesehatan, kondisi psikologis, dan menganalisis pola pemberian ASI ibu postpartum.

\section{METODE}

\section{Desain, Tempat, dan Waktu Penelitian}

Desain penelitian ini adalah cross sectional study. Penelitian dilakukan di Kecamatan Dramaga Kabupaten Bogor yang terdiri dari lima desa wilayah kerja Puskesmas Dramaga yaitu Desa Ciherang, Sukawening, Dramaga, Sinarsari, dan Neglasari. Kecamatan Dramaga dipilih secara purposive dengan pertimbangan kemudahan akses. Penelitian ini dilakukan pada bulan April-Mei 2013. Proses pengolahan, analisis, dan interpretasi data dilakukan pada bulan Juli-Oktober 2013.

\section{Jumlah dan Cara Pengambilan Subjek}

Subjek penelitian adalah ibu postpartum yang tinggal di lokasi penelitian. Penarikan subjek dilakukan secara purposive dengan kriteria inklusi antara lain 1) ibu postpartum tidak memiliki penyakit risiko tinggi; 2) usia bayi 10-40 hari pada saat pengambilan data; 3) ibu postpartum bersedia menjadi subjek yang akan ditegaskan melalui persetujuan informed consent; 4) bayi bukan merupakan persalinan pertama; 5) ibu postpartum dapat berkomunikasi dengan baik. Kerangka sampling diperoleh dari puskesmas dan bidan desa. Seluruh ibu postpartum yang memenuhi kriteria inklusi menjadi subjek penelitian.

\section{Jenis dan Cara Pengumpulan Data}

Jenis data merupakan data primer yaitu data dikumpulkan secara langsung oleh peneliti dengan menggunakan kuesioner. Data primer yang dikumpulkan meliputi karakteristik subjek (usia, pendidikan formal, pekerjaan, pendapatan keluarga, dan pengalaman menyusui), pengetahuan gizi dan kesehatan, keluhan kesehatan, kecukupan produksi ASI, kondisi psikologis postpartum, dan pola pemberian ASI yang didapatkan melalui wawancara menggunakan kuesioner.

\section{Pengolahan dan Analisis Data}

Analisis data secara deskriptif dilakukan dengan mengelompokkan atau membandingkan dengan cut off point. Untuk melakukan statistik inferensia, maka data diuji kenormalannya dengan menggunakan uji Kolmogorov-Smirnov. Uji korelasi yang dilakukan adalah uji korelasi Spearman.

Pengetahuan gizi terdiri dari sepuluh pertanyaan tentang ASI dan konsumsi makanan yang baik selama periode postpartum berdasarkan Khomsan (2009). Hasil skoring dari pertanyaan yang telah dibuat dikelompokkan menjadi kurang $(<6)$, cukup (skor 6-8), dan baik (skor>8). Keluhan kesehatan subjek yang terdiri dari sembilan poin penilaian dikategorikan menjadi rendah, sedang, dan tinggi berdasarkan kriteria Wulandari (2011). Data keluhan kesehatan ibu postpartum dikelompokkan menjadi rendah $(<3)$, sedang $(3-6)$, dan tinggi $(>6)$.

Penilaian kondisi psikologis postpartum menggunakan kuesioner Edinburgh Postnatal Depression 
Scale (EPDS), yaitu suatu instrumen yang terdiri dari 10 item yang dipakai untuk menilai adanya kemungkinan dari depresi postpartum dalam skala tertentu (Cox \& Holden 2003). Kondisi psikologis postpartum dikategorikan menjadi tidak depresi jika skor $\leq 10$ dan depresi jika skor $>10$.

Pola pemberian ASI terdiri dari inisiasi menyusui dini (IMD), durasi pemberian ASI, frekuensi pemberian ASI, kecukupan produksi ASI yang dinilai berdasarkan persepsi, dan pemberian ASI eksklusif. Kategori pola pemberian ASI berdasarkan nilai dari berjalannya praktik IMD, frekuensi pemberian $>6$ kali per hari, durasi $>10$ menit tiap kali menyusui, berjalannya perilaku ASI eksklusif, dan produksi ASI yang cukup. Kategori kecukupan produksi ASI yaitu sangat kurang jika skor $\leq 3$, kurang jika skor 3 sampai 6, dan cukup jika skor $>6$ (Kent et al. 2006).

\section{HASIL DAN PEMBAHASAN}

\section{Pengetahuan Gizi}

Tingkat pengetahuan gizi ibu postpartum tentang ASI dan pemilihan makanan yang baik selama masa postpartum tergolong cukup (Tabel 1). Sebagian besar ibu postpartum memiliki pengetahuan gizi cukup (60\%). Berdasarkan hasil tersebut pengetahuan gizi subjek relatif baik karena hanya sedikit (6.7\%) yang memiliki pengetahuan gizi kurang, meskipun sebagian besar subjek hanya menyelesaikan pendidikan sekolah dasar $(43.3 \%)$ dan SMP (36.7\%). Menurut Khomsan (2009), faktor yang berpengaruh terhadap pengetahuan tidak hanya tingkat pendidikan, namun juga pengalaman, hubungan sosial, dan paparan media massa seperti majalah, TV, dan buku.

Pengetahuan ibu dapat diperoleh melalui pendidikan formal, informal dan nonformal (Khomsan 2009). Sebagian besar pendidikan ibu postpartum adalah SD/sederajat (43.3\%). Namun ibu postpartum pada penelitian ini mendapat pengetahuan gizi yang bersumber dari bidan/petugas kesehatan (76.7\%),

Tabel 1. Sebaran Subjek berdasarkan Variabel Penelitian

\begin{tabular}{lcc}
\hline \multicolumn{1}{c}{ Variabel } & $\mathrm{n}$ & $\%$ \\
\hline Pengetahuan Gizi: & & \\
$\quad$ Baik & 10 & 33.3 \\
$\quad$ Sedang & 18 & 60.0 \\
$\quad$ Kurang & 2 & 6.7 \\
Keluhan Kesehatan: & & \\
$\quad$ Rendah & 20 & 66.7 \\
$\quad$ Sedang & 9 & 30.0 \\
$\quad$ Tinggi & 1 & 3.3 \\
Kondisi Psikologi: & & \\
$\quad$ Depresi & 17 & 56.7 \\
$\quad$ Tidak depresi & 13 & 43.3 \\
\hline
\end{tabular}

kader posyandu $(60.0 \%)$, televisi $(30.0 \%)$, keluarga (26.7\%), dan teman/tetangga (6.7\%). Hal ini selaras dengan pernyataan Bowman (2013) bahwa pengetahuan yang diperoleh ibu postpartum tentang pemberian ASI secara umum didapatkan dari sejumlah sumber seperti internet, konsultan ASI, teman, dan keluarga. Ibu postpartum pada penelitian ini paling banyak mendapat pengetahuan gizi dan informasi kesehatan yang berasal dari bidan atau petugas kesehatan $(76.7 \%)$. Namun masih banyak tenaga kesehatan yang justru mempromosikan susu formula sehingga sebesar $43.3 \%$ ibu postpartum tidak memberikan ASI secara eksklusif.

\section{Keluhan Kesehatan Ibu Postpartum}

Sebagian besar ibu memiliki keluhan kesehatan rendah (66.7\%) (Tabel 1). Lamanya penyembuhan setelah melahirkan (masa postpartum) dapat dipengaruhi juga oleh pelayanan postpartum yang meliputi pengawasan ibu oleh tenaga kesehatan selama dua jam pertama setelah melahirkan (persalinan kala IV) (Prawirohardjo 2008). Keluhan kesehatan dipengaruhi oleh pelayanan dan perawatan kesehatan yang dilakukan oleh petugas kesehatan maupun secara mandiri (swamedikasi). Perawatan yang dilakukan subjek adalah kontrol bidan atau tenaga kesehatan lainnya, pijat atau urut, dan mengonsumsi obat serta jamu tradisional.

Kematian ibu dan bayi di Indonesia masih relatif tinggi dan hal ini sering berkaitan dengan pola perawatan kehamilan, persalinan, dan postpartum. Evance et al. (2013) juga menyebutkan bahwa terdapat dua faktor risiko yang signifikan dalam memengaruhi angka kematian ibu. Faktor pertambahan usia ibu dan status perkawinan adalah faktor-faktor yang ditemukan terkait dengan peningkatan risiko kematian ibu.

Sebagian besar ibu postpartum melakukan perawatan masa postpartum dengan mengonsumsi jamu tradisional $(96.7 \%)$ dan melakukan kontrol oleh bidan (50\%). Jamu tradisional yang dikonsumsi ibu postpartum adalah godogan lempuyang (Zingiber aromaticum VAL) (20.0\%), godogan beluntas (Pluchea indica LES) (10.0\%), kunyit asem (30.0\%), air sirih (13.3\%), beras kencur (56.7\%), dan jamu kemasan (36.7\%). Sebanyak 30\% subjek mengonsumsi lebih dari satu jenis jamu tradisional. Sementara hasil penelitian Dahlianti et al. (2005) menunjukkan sebagian besar ibu postpartum mengonsumsi jamu galohgor dengan manfaat yang dirasakan adalah kebugaran tubuh dan penyembuhan rahim setelah melahirkan (76.7\%).

\section{Kondisi Psikologis Postpartum}

Sebagian besar ibu postpartum $(56.7 \%)$ tergolong mengalami depresi (Tabel 1) dan sebagian lainnya tidak mengalami depresi (43.3\%). Prevalensi depresi di lokasi penelitian ternyata lebih tinggi dibandingkan hasil penelitian Riordan (2005) yang menunjukkan bahwa sebanyak $20 \%$ perempuan se- 
telah melahirkan memiliki depresi ringan sampai sedang.

Hasil wawancara ibu postpartum menunjukkan bahwa ibu postpartum mengalami depresi karena alasan khawatir dan cemas tanpa alasan. Alasan depresi yang lain disebabkan oleh rasa sedih dan jengkel tanpa alasan. Ibu postpartum mengalami depresi disebabkan oleh faktor ekonomi. Sebagian subjek dalam penelitian ini tergolong keluarga miskin $(50.0 \%)$. Hal ini didukung oleh pernyataan Riordan (2005) bahwa ibu postpartum dapat mengalami stres karena hubungan yang mendukung kejadian tersebut, salah satunya karena faktor ekonomi. Selain itu peranan suami menentukan kelancaran refleks pengeluaran ASI (let down reflex) yang sangat dipengaruhi oleh keadaan perasaan ibu.

\section{Pola Pemberian ASI}

Sebagian besar ibu postpartum melakukan praktek IMD (80\%). Faktor yang memengaruhi praktek IMD adalah pelayanan dan perawatan tenaga kesehatan, contohnya yaitu bidan dan dokter. Hampir seluruh ibu postpartum melakukan persalinan di bidan (96.7\%). Hal ini sejalan dengan penelitian Sari (2012) yang menjelaskan bahwa faktor-faktor yang memengaruhi kegagalan praktek IMD, diantaranya adalah penolong persalinan (bidan) dan promosi susu formula. Wulandari (2011) juga menyebutkan bahwa metode memisahkan ibu dengan bayi ternyata membuat daya tahan tubuh bayi menurun hingga mencapai $25 \%$.

Sebagian besar ibu postpartum memiliki produksi ASI yang cukup (90\%). Ibu postpartum sebagian besar memberikan ASI dengan durasi lebih dari 10 menit (90\%). Seluruh subjek memberikan ASI lebih dari 6 kali per hari. Pemberian ASI eksklusif dilakukan oleh $43.3 \%$ ibu postpartum dan sebanyak $56.7 \%$ ibu telah memberikan makanan prelakteal kepada bayinya (Tabel 2).

Berdasarkan penelitian Kronborg dan Vaeth (2004), lima minggu pertama kelahiran merupakan periode penting untuk memengaruhi durasi pemberian ASI eksklusif karena sebagian besar penghentian terjadi selama periode itu. Hal ini selaras dengan pernyataan Dadhich dan Agarwal (2009) bahwa IMD, pemberian ASI eksklusif, dan umur pengenalan MPASI merupakan intervensi utama dalam mencapai tujuan MDGs dalam upaya menanggulangi mortalitas dan malnutrisi pada anak.

\section{Hubungan antara Pengetahuan Gizi dengan Pola Pemberian ASI}

Pertanyaan dengan persentase jawaban benar paling sedikit adalah untuk pertanyaan yang terkait dengan: 1) kolostrum (33.3\%), 2) definisi ASI eksklusif (56.7\%), dan 3) makanan yang terbaik bagi bayi (66.7\%). Subjek yang memiliki pengetahuan tentang kolostrum dan makanan terbaik bagi bayi cenderung memberikan ASI eksklusif. Pemberian kolostrum pada penelitian ini lebih rendah jika
Tabel 2. Sebaran Subjek berdasarkan Pola Pemberian ASI

\begin{tabular}{lcc}
\hline \multicolumn{1}{c}{ Pola Pemberian ASI } & $\mathrm{n}$ & $\%$ \\
\hline IMD: & 24 & 80.0 \\
$\quad$ Ya & 6 & 20.0 \\
$\quad$ Tidak & & \\
Kecukupan Produksi ASI: & 27 & 90.0 \\
$\quad$ Cukup & 3 & 10.0 \\
$\quad$ Kurang & & \\
Durasi Pemberian: & 27 & 90.0 \\
$\quad>10$ menit & 3 & 10.0 \\
$\quad \leq 10$ menit & & \\
Frekuensi Pemberian: & 30 & 100.0 \\
$\quad>6$ kali/hari & 0 & 0.0 \\
$\quad \leq 6$ kali/hari & & \\
Pemberian ASI Eksklusif: & 17 & 56.7 \\
$\quad$ Ya & 13 & 43.3 \\
$\quad$ Tidak (penambahan prelakteal)
\end{tabular}

dibandingkan penelitian Papona et al. (2013) yaitu sebesar $55 \%$. Semakin tinggi pemahaman ibu terkait kolostrum $(p=0.074)$ dan makanan terbaik yang diberikan untuk bayi ( $p=0.039)$, maka semakin meningkatkan kecenderungan pemberian ASI eksklusif. Data uji hubungan tabulasi silang selengkapnya dapat dilihat pada Tabel 3.

Tabel 3. Tabulasi Silang Pengetahuan Gizi dengan Pemberian ASI Eksklusif

\begin{tabular}{llll}
\hline \multirow{2}{*}{$\begin{array}{c}\text { Pertanyaan } \\
\text { Pengetahuan Gizi }\end{array}$} & \multicolumn{2}{c}{$\begin{array}{c}\text { Pemberian ASI } \\
\text { Eksklusif (\%) }\end{array}$} & \multirow{2}{*}{ Total } \\
\cline { 2 - 3 } & \multicolumn{2}{c}{ Ya } & \multicolumn{2}{c}{ Tidak } & \\
\hline $\begin{array}{l}\text { Kolostrum: } \\
\quad \text { Ya }\end{array}$ & 23.3 & 10.0 & 33.3 \\
$\quad 33.3$ & 33.3 & 66.7 \\
$\quad$ Tidak & & & \\
$\begin{array}{l}\text { Definisi ASI eksklusif: } \\
\quad \text { Ya }\end{array}$ & 26.7 & 30.0 & 56.7 \\
$\quad$ Tidak & 30.0 & 13.3 & 43.3 \\
$\begin{array}{l}\text { Makanan terbaik } \\
\text { bagi bayi: }\end{array}$ & & & \\
$\quad$ Ya & 43.3 & 23.3 & 66.7 \\
$\quad$ Tidak & 13.3 & 20.0 & 33.3 \\
\hline
\end{tabular}

Namun perilaku pemberian ASI eksklusif tidak hanya ditentukan oleh pemahaman ibu mengenai kolostrum dan makanan terbaik bagi bayi. Lebih jauh Roesli (2008) memaparkan perilaku pemberian ASI juga didasarkan pada naluri keibuan, sehingga tidak hanya dipengaruhi oleh pengetahuan. Hasil penelitian Forster et al. (2006) pada ibu postpartum di Australia juga menunjukkan bahwa faktor positif yang dapat memengaruhi pemberian ASI pada ibu postpartum diantaranya adalah keinginan yang sangat kuat untuk memberikan ASI dan telah 
mengonsumsi ASI saat masih bayi. Rahman et al. (2013) juga memaparkan bahwa motivasi dan dukungan dari petugas kesehatan sangat diharapkan mengingat pentingnya manfaat pemberian ASI dan pemberian asuhan terbaik untuk bayi.

\section{Hubungan antara Keluhan Kesehatan dengan Pola Pemberian ASI}

Berdasarkan hasil tabulasi silang (Tabel 4), terdapat kecenderungan bahwa semakin rendah keluhan kesehatan ibu postpartum, maka pola pemberian ASI semakin baik $(p=0.74 ; r=0.063)$. Demikian pula semakin baik praktik IMD, produksi ASI semakin cukup, frekuensi dan durasi pemberian ASI, serta pemberian ASI secara eksklusif yang cenderung semakin meningkat.

Keluhan kesehatan yang paling banyak dialami adalah terkait dengan gangguan pada payudara yang sangat menentukan keberhasilan proses laktasi. Keluhan tersebut adalah puting susu yang lecet dan pembendungan ASI yang masing-masing dialami oleh $50.0 \%$ ibu postpartum. Sedangkan keluhan yang paling sedikit dialami yaitu keluhan air seni tertahan (3.3\%). Subjek yang mengalami gangguan puting lecet cenderung tetap memberikan ASI secara eksklusif dibandingkan dengan subjek dengan gangguan pembendungan ASI. Puting susu lecet menurut Apriyanti (2012) dapat disebabkan oleh teknik menyusui yang salah atau perawatan yang tidak benar pada payudara. Selain itu, apabila terjadi pembendungan ASI pada payudara dan puting terasa nyeri, maka akan lebih baik bila ASI dikeluarkan.

Berdasarkan hasil penelitian Mawaddah dan Hardinsyah (2008) sebanyak $82 \%$ ibu sejak hamil melakukan perawatan payudara dan hampir seluruhnya berencana memberikan ASI eksklusif sampai bayi berusia enam bulan (94\%). Hasil analisis ini mengacu pada pernyataan Ahn dan Youngblut (2007) yang menyatakan bahwa keluhan kesehatan ibu postpartum justru berkaitan erat dengan kesehatan bayi yang sedang diberi ASI. Sari (2013) juga menyatakan bahwa pola pemberian ASI dipengaruhi oleh tenaga kesehatan dan pelaksanaan program pelayanan kesehatan. Data uji hubungan selengkapnya disajikan pada Tabel 5 .

Perawatan kesehatan ini merupakan salah satu upaya untuk mengurangi risiko gangguan kesehatan ibu postpartum yang akan berdampak lebih luas pada kematian ibu postpartum. Hasil penelitian yang dilakukan di Meksiko oleh Romero et al. (2007)
Tabel 5. Tabel Hubungan Keluhan Kesehatan dengan Perilaku ASI Eksklusif

\begin{tabular}{|c|c|c|c|}
\hline \multirow{2}{*}{$\begin{array}{l}\text { Jenis Keluhan } \\
\text { Kesehatan }\end{array}$} & \multicolumn{2}{|c|}{$\begin{array}{l}\text { Perilaku ASI } \\
\text { Eksklusif (\%) }\end{array}$} & \multirow[t]{2}{*}{ Total } \\
\hline & $\overline{Y a}$ & Tidak & \\
\hline \multicolumn{4}{|l|}{ Puting susu lecet: } \\
\hline Ya & 40.0 & 20.0 & 60.0 \\
\hline Tidak & 16.7 & 23.3 & 40.0 \\
\hline Total & 56.7 & 43.3 & 100.0 \\
\hline \multicolumn{4}{|l|}{ Pembendungan ASI: } \\
\hline Ya & 26.7 & 33.3 & 60.0 \\
\hline Tidak & 26.7 & 13.3 & 40.0 \\
\hline Total & 53.4 & 46.6 & 100.0 \\
\hline
\end{tabular}

menemukan bahwa penyebab paling umum kematian ibu adalah komplikasi aborsi, perdarahan, dan gangguan sepsis.

\section{Hubungan antara Kondisi Psikologis dengan Pola Pemberian ASI}

Kondisi psikologis tidak menunjukkan kecenderungan korelasi dengan pola pemberian ASI ( $r=-$ 0.107; $p=0.574$ ). Hasil yang sama ditunjukkan pada uji hubungan antara pertanyaan yang menunjukkan kondisi psikologis dengan pemberian ASI eksklusif.

Ibu postpartum yang menjadi subjek penelitian ini seluruhnya mengalami baby blues syndrome dengan pengalaman persalinan lebih dari satu kali. Sebagian besar ibu yang mengalami depresi tetap melakukan praktek IMD, memberikan ASI eksklusif (40\%), bahkan kecukupan produksi ASI tergolong cukup. Berbeda dengan pendapat Riordan (2005) yang memaparkan bahwa Ibu yang mengalami depresi memiliki risiko 1.25 kali lebih besar untuk berhenti menyusui. Namun dalam penelitian ini sebagian ibu postpartum tetap memberikan ASI meski mengalami depresi.

Yuliastanti (2003) menyebutkan bahwa dukungan dari keluarga, teman, terutama pasangan merupakan faktor yang juga penting untuk diperhatikan karena dengan adanya dukungan dari lingkungan memberikan dorongan positif yang kuat bagi ibu untuk memberikan ASI. Hasil penelitian Nazara (2009) juga mengungkapkan bahwa depresi postpartum dapat dipengaruhi oleh tingkat pendidikan ibu dan dukungan keluarga. ASI selain memiliki manfaat ditinjau dari segi gizi dan kesehatan, juga menguntungkan secara ekonomi karena dapat menghemat pengeluaran pangan untuk bayi (susu formula).

Tabel 4. Tabulasi Silang Keluhan Kesehatan dengan Pola Pemberian ASI

\begin{tabular}{|c|c|c|c|c|c|c|c|c|c|c|}
\hline \multirow{3}{*}{$\begin{array}{c}\text { Keluhan } \\
\text { Kesehatan (\%) }\end{array}$} & \multicolumn{10}{|c|}{ Pola Pemberian ASI Ibu Postpartum } \\
\hline & \multicolumn{2}{|c|}{ IMD (\%) } & \multicolumn{2}{|c|}{$\begin{array}{l}\text { Kecukupan } \\
\text { Produksi (\%) }\end{array}$} & \multicolumn{2}{|c|}{ Frekuensi (\%) } & \multicolumn{2}{|c|}{ Durasi (\%) } & \multicolumn{2}{|c|}{$\begin{array}{c}\text { ASI Eksklusif } \\
(\%)\end{array}$} \\
\hline & Ya & Tidak & Cukup & Sedang & $\begin{array}{c}\leq 6 \mathrm{kali} / \\
\text { hari }\end{array}$ & $\begin{array}{l}>6 \mathrm{kali} / \\
\text { hari } \\
\end{array}$ & $\begin{array}{l}\leq 10 \\
\text { menit }\end{array}$ & $\begin{array}{l}>10 \\
\text { menit }\end{array}$ & $\mathrm{Ya}$ & Tidak \\
\hline Rendah & 63.3 & 3.3 & 60.0 & 6.7 & 0.0 & 66.7 & 6.7 & 60.0 & 40.0 & 26.7 \\
\hline Sedang & 16.7 & 13.3 & 26.7 & 3.3 & 0.0 & 30.0 & 3.3 & 26.7 & 3.3 & 26.7 \\
\hline Tinggi & 0.0 & 3.3 & 3.3 & 0.0 & 0.0 & 3.3 & 0.0 & 3.3 & 3.3 & 0.0 \\
\hline
\end{tabular}

JGP, Volume 8, Nomor 3, November 2013 


\section{KESIMPULAN}

Mayoritas ibu postpartum melakukan praktek IMD dan dalam kategori cukup memberikan ASI. Durasi pemberian ASI sebagian besar ibu postpartum dan frekuensi pemberian ASI seluruh subjek tergolong baik. Pemberian ASI eksklusif dilakukan oleh sebanyak 43.3\% subjek. Pengetahuan gizi tentang definisi ASI yang semakin baik pada ibu postpartum berkorelasi dengan pemberian ASI eksklusif yang baik $(r=0.126 ; p=0.508)$. Semakin rendah keluhan kesehatan ibu postpartum, cenderung berkorelasi dengan pola pemberian ASI $(r=0.063 ; p=0.74)$ yang semakin baik.

\section{UCAPAN TERIMA KASIH}

Ucapan terima kasih penulis sampaikan kepada Puskesmas wilayah kerja Kecamatan Dramaga, Kabupaten Bogor yang telah memberikan izin kepada penulis untuk menggunakan lokasi penelitian.

\section{DAFTAR PUSTAKA}

Ahn S \& Youngblut JM. 2007. Predictors of women's postpartum health status in the first 3 months after childbirth. Asian Nursing Research, 1(2), 136-146.

Apriyanti A. 2012. Gambaran perawatan payudara pada ibu nifas di BPS Sri Sugiyartiningsih Tawangmangu Karanganyar Tahun 2012. Jurnal Maternal, Volume 6 April 2012.

[CDC] Centers for Disease Control and Prevention, Division of Nutrition, Physical Activity and Obesity, National Center for Chronic Disease Prevention and Health Promotion. 2012. Breastfeeding Report Card United States, 2012. http://www.cdc.gov/breastfeeding/pdf [21 September 2013].

Dadhich JP \& Agarwal RK. 2009. Mainstreaming early and exclusive breastfeeding for improving child survival. Journal of Indian Pediatrics 2009; 46, 11-7.

Dahlianti R, Nasoetion A, \& Roosita K. 2005. Keragaan perawatan kesehatan masa nifas, pola konsumsi jamu tradisional dan pengaruhnya pada ibu nifas di Desa Sukajadi, Kecamatan Tamansari, Bogor. Jurnal Media Gizi dan Keluarga, 29(2), 55-65.

[Depkes RI] Departemen Kesehatan Republik Indonesia. 2013. Profil Kesehatan Indonesia 2012. Departemen Kesehatan RI, Jakarta.

Evance I et al. 2013. Causes and risk factors for maternal mortality in rural Tanzania, Case of Rufiji Health and Demographic Surveillance Site (HDSS). African Journal of Reproductive Health; September 2013, 17(3).

Forster DA, McLachlan HL, \& Lumley J. 2006. Factors associated with breastfeeding at six months postpartum in a group of Australian women. International Breastfeeding Journal, 1, 18.
Kent JC, Mitoulas LR, Cregan MD, Ramsay DT, Doherty DA, \& Hartmann PE. 2006. Volume and frequency of breastfeedings and fat content of breast milk throughout the day. Pediatrics , 117:e387. doi:10.1542/peds.2005-1417.

Khomsan A \& Rachmadewi A. 2009. Pengetahuan, sikap, dan praktek ASI eksklusif serta status gizi bayi usia 4-12 bulan di pedesaan dan perkotaan. Jurnal Gizi dan Pangan, 4(2), 8390.

Kronborg H \& Vaeth M. 2004. The influence of psychosocial factors on the duration of breastfeeding. Scand Journal of Public Health, 32, 210.

Mawaddah N \& Hardinsyah. 2008. Pengetahuan, sikap, dan praktek gizi serta tingkat konsumsi ibu hamil di Kelurahan Kramat Jati dan Kelurahan Ragunan Provinsi DKI Jakarta. Jurnal Gizi dan Pangan, 3(1), 30-42.

Nazara Y. 2009. Efektivitas psikoedukasi terhadap pencegahan depresi pascasalin. Jurnal Obstetri dan Ginekologi Indonesia, 33(4).

Papona N, Laoh J, \& Palandeng H. 2013. Hubungan pengetahuan dan sikap ibu nifas tentang pemberian kolostrum pada bayi baru lahir di Puskesmas Ulu Kecamatan Siau Timur Kabupaten Kepulauan Sitaro. Jurnal Keperawatan, 1(1), Agustus 2013.

Prawiroharjo S. 2008. Ilmu Kebidanan. Yayasan Bina Pustaka, Jakarta.

Rachman WA, Hariyanti E, \& Riskiyani S. 2013. Penerapan strategi promosi kesehatan pada pemberian inisiasi menyusui dini di Rumah Bersalin Sophiara Makassar 2009. Jurnal Administrasi Kebijakan Kesehatan, 2(1), 27-34.

Romero GG et al. 2007. Risk factors of maternal death in Mexico. Birth Issues in Perinatal Care, 34(1), 21-5.

Riordan J. 2005. Breastfeeding and Human Lactation: Third Edition. Jonesand Bartlett Publishers, Sudbury.

[Kemenkes RI] Kementerian Kesehatan Republik Indonesia. 2011. Laporan Nasional Riset Kesehatan Dasar (Riskesdas) 2010. Kemenkes, Jakarta.

Sari YS. 2013. Analisis implementasi program pemberian ASI Eksklusif di Puskesmas Brangsong 02 Kabupaten Kendal. Jurnal Kesehatan Masyarakat, 2(1).

Taveras EM et al. 2003. Clinician support and psychosocial risk factors associated with breastfeeding discontinuation. Jurnal of Pediatrics, 112, 108-15.

Wulandari AS. 2011. Inisiasi menyusui dini untuk awali ASI Eksklusif. Jurnal Ilmu Kesehatan, 1 (2), Juli 2011.

Yuliastanti T. 2013. Keberhasilan bounding attachment. Jurnal Kebidanan, V(02), Desember 2013. 